\title{
Tools and methods of work of law enforcement agencies in the sphere of economic law infringements
}

\author{
OLENA KOZYNETS ${ }^{1}$, ALLA NITCHENKO ${ }^{2}$, ANDRII KHOLOSTENKO ${ }^{3}$, PETRO ZHOVTAN $^{4}$, \\ LARYSA LUHOSH ${ }^{5}$
}

\author{
${ }^{1}$ Department of law enforcement and general legal disciplines, Chernihiv Polytechnic National \\ University, UKRAINE \\ ${ }^{2}$ Department of law enforcement and general legal disciplines, Chernihiv Polytechnic National \\ University, UKRAINE \\ ${ }^{3}$ Department of Criminal Procedure, Odessa State University of Internal Affairs, UKRAINE \\ ${ }^{4}$ Department of Criminal Procedure, Odessa State University of Internal Affairs, UKRAINE \\ ${ }^{5}$ Department of Management, Finance and Information Technology, Augustyn Voloshin Carpathian \\ University, UKRAINE
}

\begin{abstract}
The global transformations of the economy through the system of information technologies have led to the spread of new manifestations of crime, mainly in the areas of money transfer, foreign exchange transactions, international logistics schemes. Consequently, there is a need to develop highly effective tools and methods of law enforcement agencies in the sphere of economic law infringements. The purpose of the research is to investigate modern tools and methods used in the activities of law enforcement agencies in order to prevent economic law infringements. The research methods are as follows: systematization, generalization, analysis of the regulatory framework, the method of comparative analysis; system and logical analysis, method of information synthesis; quantitative method. Results. The means and methods of work of law enforcement agencies in the field of economic law infringements have been analyzed in the academic paper. A comparative analysis of the application of tools and methods of law enforcement agencies in the field of economic law infringements in European countries has been conducted. It has been noted that they have been experiencing significant structural and technological changes, which makes it possible to more effectively identify economic violations of the law and prevent their implementation in various spheres of economic activity. The necessity of introducing modern information and technological methods of work of law enforcement agencies in order to overcome the growing number of economic law infringements has been proved. The concept of modern tools and methods of counteraction to economic law infringements has been considered and the further development of system of means and methods of counteraction to economic law infringements has been offered. The results of the research can be used to study trends in the development of tools and methods of law enforcement agencies in the field of economic violations of the law.
\end{abstract}

Key-Words: - Economic Law Infringements (Violations of the Law), Economic Crime, Methods of Work of Law Enforcement Agencies, Counteraction to Economic Law Infringements, Prevention, Detection, Models of Deterring Law Infringements.

Received: October 5, 2020. Revised: March 10, 2021. Accepted: March 20, 2021. Published: April 1, 2021.

\section{Introduction}

The modern economy goes beyond individual countries; it becomes global, which increases the scale of economic abuse and ensures their organization. Such trends require scientific and practical rethinking of the system of economic law infringements, as well as ways and methods of their detection and overcoming. In accordance with the latest international challenges, law enforcement agencies are reorganizing their work in the direction of rapid response to premonition and prevention of the manifestation of economic law infringements using analytical systems and software algorithms. Modern challenges require the 
concept's scientific substantiation of development of tools and methods in order to combat economic violations of the law, taking into account the introduction of digital technologies in all spheres of public life and public administration [1]. Undoubtedly, technologies are changing the way law enforcement agencies works around the world, forasmuch as they affect the analysis of criminal cases and investigations [2]. This necessitates the improvement and development of tools and methods of work of law enforcement agencies in the sphere of economic violations of the law.

The purpose of the research is to investigate modern tools and methods used in the activities of law enforcement agencies in order to prevent economic law infringements.

The research objectives are as follows:

1. To identify the means and methods of work of law enforcement agencies in the prevention and overcoming of economic violations of the law.

2. To evaluate the nature and trends of economic abuse in the world dimension.

\section{Literature review}

Economic law infringements are considered as economic crimes in the scientific literature [3; 4]. Some scientific studies of economic crimes do not take into account the definition of the category of economic violations of the law $[2 ; 5]$. Even when definitions of economic crimes are given, they are limited only to violations of the law against property and business practices $[6 ; 7]$ and do not take into account a wide range of other criminal acts in the field of economy. After all, not all economic law infringements have the nature of a crime; some of them manifest themselves in the form of guilt [8].

Scientists offer the following approaches to the classification of economic law infringements:

1.Violation of property rights [9].

2.Violation of the right to economic activity [10].

3.Law infringements in administration (management) $[11 ; 12 ; 13]$.

Committee of Ministers of the Council of Europe has identified 16 violations of the law as economic crimes, namely: cartel crimes; fraudulent practices and abuse of the economic situation of multinational companies; fraudulent procurement or misuse of state or international grants; cybercrime; fictitious firms; forgery of company balance sheets and accounting violations of the law; fraud against the economic situation and corporate capital of companies; violation by the company of safety and health standards for employees; credit fraud; fraud of consumers; unfair competition, including bribes and deceptive advertising; fiscal law infringements; customs violations of the law; offenses related to monetary and currency norms; stock exchange and banking law infringements; offenses against the environment [14]. At the same time, Peter Grabosky identifies the following types of economic law infringements, namely: insurance fraud, fraud against the government, fraud against employers, fraud against consumers, fraud in the telemarketing market, fraud against shareholders and investors, fraud in the payment of pensions, bribery and corruption, money laundering, telecommunications fraud, fraud connected with credit cards, industrial espionage, intellectual property theft, forgery, business fraud, electronic fraud with transfer of funds) [15].

The lecture given at the Tamil Nadu State Judicial Academy during the training specialists on the positions of district judges provides a classification of economic law infringements [16]. The following types of economic law infringements are distinguished, namely: fraud with importexport; banking fraud; insurance fraud; foreign currency fraud; smuggling of narcotic drugs and psychotropic substances; forgery of travel documents, identity cards; counterfeit currency and counterfeit government stamps/papers; cybercrime; infringement of intellectual property rights, audio and video piracy, software piracy, etc.

Berghoff, Hartmut, Spiekermann, Uwe in their research analyze six features of economic crime, namely: the predominant role of upper and middle class in the organization and commission of these crimes, motivation for financial gain, nonviolence, systemic nature, breach of trust and diffuse victimization [17]. Some authors study the impact of corruption and the shadow economy as a type of economic crime $[18 ; 19]$. The review of international law and practice regarding crimes committed in the field of business conducted by the Institute of Chartered Accountants of England and Wales is also especially noteworthy. This analysis has identified the basic types of entrepreneurial crime in the field of entrepreneurial activity, the purpose of which is to obtain unfair benefits for the business or its owners or employees [20].

Comparing the current challenges and trends of financial criminal law in Europe and the United States, Katalin Ligeti \& Vanessa Franssen introduce and explain the category of "economic and financial criminal law" as a branch of criminal law; this category concerns the criminal enforcement and sanctioning of violations of 
regulations in the field of economics and finance [21].

The Swedish National Council for Crime Prevention analyzes methods for preventing economic law infringements and presents a pyramidal model of combating economic law infringements, which includes a hierarchy of measures to combat violations of law [22]. A similar study is conducted by Mirko Draca \& Stephen Machin, who study the relationship between crime and economic incentives, on the basis of which they have developed an economic model of crime. This model links the motives for committing economic crimes to the level of wages [10].

Wang Liang \& Zhao Jihong Solomon have conducted a comparative study of crime strategies in the United States and China [23]. Tayebi \& Glässer [1] have analyzed social networks for forecasting activity of law enforcement agencies. Such analysis justifies the use of effective tools in predicting economic law infringements. Some relevant studies can be found in [24] and [25].

Yarik Kryvoi consideres the different approaches used by tribunals to matters relating to jurisdiction, applicable law, norms of control, norms of evidence, respect for the actions of national courts and regulatory bodies related to economic crimes [26]. This study is supplemented by Kofanova et al., who have revealed, that during the period of independence of Ukraine the level of economic crimes increased by almost 300\% [27]. Besides Kvasha et al., have proposed amendments to the current criminal legislation of Ukraine on economic violations of the law [28]. Yanovska et al., have generalized approaches to understanding the nature and structure of economic crimes and analyzed effective ways to protect property in the investigation of economic crimes. Im addition Mozol et al., have identified the basic trends in the field of economic crime, namely: globalization, the creation of transnational criminal organizations and groups of "white-collar employees", whose coordinated actions affect certain economic and political processes of the country; the transition of economic crime in the technological plane [30]. The authors propose measures to combat economic crime at the level of implementation of the coordinating powers of law enforcement agencies, namely: to improve the forms and methods of cooperation in the fight against crime towards the implementation of the powers of law enforcement agencies; they also propose heads of law enforcement agencies in the areas of interaction in the fight against crime and corruption to take additional measures in order to increase the effectiveness of combating crime and the state of detecting criminal law infringements.

Thus, the direction of explaining economic law infringements under market conditions for economically developed economies dominates in the scientific research. Economic crime is growing and becoming a global problem. Consequently, the means and methods of work of law enforcement agencies in combating such challenges require further research and evaluation of their practical application.

\section{Methods of the research}

The implementation of the research purpose provides involvement of the following methods, namely:

-systematization, generalization of scientific publications on the matters of economic law infringements;

- analysis of the regulatory framework of EU countries concerning improving the tools and methods of work of law enforcement agencies in the field of economic violations of the law;

- method of comparative analysis;

-system and logical analysis, method of information synthesis;

- quantitative method for studying the number of economic law infringements.

The study was conducted on the basis of information and analytical materials of international organizations including: Transparency International, European Financial and Economic Crime Centre, European Commission, Institute of Chartered Accountants of England and Wales [31; $32 ; 33 ; 20]$ as well as the National Anti-Corruption Bureau of Ukraine, National Police of Ukraine.

The dynamics of economic violations of the law in European countries were analyzed through the crime index (CI) and GDP per capita according to data from the global database Numbeo [34]. Statistical Package for the Social Sciences was used to determine the level of economic offenses in corruption schemes.

In particular, the functional capabilities, tasks, methods of the National Police of Ukraine for counteracting economic offenses were analyzed, as well as the current legislation of Ukraine was studied [35]. To compare methods and means of counteracting economic violations, the experience of EU countries (including the Netherlands, the Great Britain, Germany, France and others) was used, on the basis of which the Concept of modern tools and methods of combating economic law 
infringements was developed and elements of a proactive system for combating economic violations of the law are also proposed.

\section{Results}

Control over the observance of legal norms of Ukraine is entrusted to law enforcement agencies, namely: the prosecutor's office, the National Police, the security services, Military Law Enforcement Service in the Armed Forces of Ukraine, the National Anti-Corruption Bureau of Ukraine, state border protection bodies, revenue and duties authorities, bodies and institutions of sentence enforcement, pre-trial detention centers, bodies of state financial control, fishery protection, state forest protection, other bodies performing law-application or law enforcement functions. Their functions are defined by different laws and have specifics in execution. According to The Law on National Police of Ukraine, the function of the police is to perform only four duties, namely:

- ensuring public safety and order;

- protection of human rights and freedoms, as well as the interests of the society and the state;

- combating crime;

-providing, within the limits determined by law, assistance services to persons who, for personal, economic, social reasons or due to emergencies, need such assistance.

Performing the functions of law enforcement agencies requires the use of a certain methodological approach. Such approach in the field of economic law infringements forces to apply the appropriate tools and methods of work of these authorities. The method of work of law enforcement agencies in the field of economic law infringements should be understood as a method of actions or combating towards reducing the number of economic violations of the law within the territory of the country and preventing their systemic application in the international space. In a broader sense, such actions are the implementation of the corresponding policy of the state; it makes it possible to raise the level of consciousness of all members of the society towards understanding the deep processes of the society development and its economic and legal aspects. The methods depend on the objectives set, the implementation functions and the nature of the influence on the subjects. Preventive methods of avoiding economic law infringements are comprehensive activities aimed at exclusion the commission of probable economic violations of the law, in which a criminal intent has not been formed yet. These methods introduce measures that prevent the implementation of undesirable phenomena, events, connections, the consequences of an economic law infringements. These measures are as follows:

-anticipating the occurrence of phenomena and processes in case of economic law infringements;

- limiting their spread or weakening their effect;

-its complete or partial elimination;

- protection of persons and various material and spiritual values and goods from possible illegal economic encroachments.

Proactive prevention is a method of preventive activity by specialized subjects aimed at avoiding the emergence and spread of criminogenic phenomena and processes in public life. Proactive prevention informs the authorities in advance about socially dangerous phenomena that may arise in the event of the implementation of certain socialeconomic measures and directly or indirectly determine certain manifestations of the law infringements, for example, to timely regulate public relations in order to eliminate the causes and conditions of future (possible) violations of the law in this way.

The basic factors of economic offenses are as follows: poverty, unemployment, lack of affordable housing, imperfection of the education system; exacerbation of social inequality; social factors related to migration processes; destruction of cultural identity, loss of moral principles of public life and patriotism, anti-social way of life; deteriorating living conditions of certain social groups, insufficient network of cultural and domestic facilities, sports facilities, recreation areas; low level of medical care; alcoholism, nonmedical use of drugs and other psychotropic substances; the dissemination of ideas and attitudes in the media leading to an increase in intolerance, violence and deception; unlimited access of minors to gambling business; shortcomings in the protection of state and collective property and other conditions that contribute to the commission of law infringements in the society.

In Ukraine, such means of work of law enforcement agencies in the field of economic law infringements, as criminological examination, explanation of provisions of the legislation, criminological research are applied at the highest level of state regulation.

Criminological expert examination of projects or current laws and other regulations is carried out in order to determine their compliance with the social needs of the society in the field of law and order, to identify possible consequences of a 
criminogenic nature as a result of their adoption and application. Criminological expert examination may be appointed by the subjects of crime prevention.

Criminological investigation is carried out in order to identify signs of preparation of law infringements, study the reasons and conditions for the commission of violations of the law, conscious or unconscious creation of conditions conducive to the commission of offenses, as well as in order to predict the impact of certain circumstances on the state of law and order in the future and justify the need and direction of preventive measures. In practice, the prevention of economic crimes, persuasion is implemented in various forms, namely: legal education; constant informing the population about the state of law and order and combating economic crimes; agitation and explanatory work among the population; criticism of anti-social manifestations; application of incentive measures; work with offenders, persons from so-called risk groups.

At the state level, the tools of combating economic law infringements are as follows:

1. Organization of research in order to study the situation on economic crime.

2. Conducting monitoring and control over the implementation of legislative acts on actions, prevention and settlement of conflicts of interest in the activities of law enforcement agencies and business structures.

3. Coordination and provision of methodological assistance in identifying economic crimes, implementing measures to eliminate them and preparing and introducing relevant programs at the local and regional levels.

4. Providing methodological support and analysis of the effectiveness of the activities of law enforcement agencies in order to prevent and overcome economic violations of the law.

5. Organization of training, retraining and advanced training on issues related to the prevention of economic law infringements of employees of state bodies and officials of local government authorities.

6. Involvement of the public in the formation, implementation and monitoring of policies to overcome economic law infringements.

The outlined methods and tools of work of law enforcement agencies in the sphere of economic law infringements in practice have turned out to be incapacitated during the transformation of the Ukrainian economy. This has led to an increase in the level of economic violations of the law due to the inefficiency of their organization and application and high labor costs of law enforcement officers, as well as the lack of appropriate level of practical skills and professional training.

In world practice, more modern methods of overcoming economic law infringements have been developed, however, they have a specific application, which depends on the mentality of a particular nation-state and the level of socialeconomic development of the country.A public electronic program "Open" has been introduced in South Korea; it allows to carry out an online control system for the consideration of any appeals and cases in violation of the law. Methods and tools of combating economic law infringements in this country are characterized by an open decisionmaking mechanism by officials, which provides:

-reduction of direct contacts with officials who license and control the activities of business entities;

-reducing the number of signatures in the necessary documents for submission and consideration in the field of economic activity (permits for land expropriation, construction, etc.);

-introduction of direct appeal to officials;

-implementation of so-called integrity agreements (the obligation not to take bribes between officials and applicants for construction work or suppliers of material and technical goods and services).

Measures to combat economic law infringements in the Netherlands are characterized by an institutional focus and include:

- constant reporting on economic violations of the law and public discussion of consequences and penalties;

-development of a monitoring system for possible zones of economic abuse in the activities of state and public organizations;

-basic measure of punishment - a ban on working in public positions and the loss of all social benefits (pension, social services);

- maintaining a register on the detection of errors of officials, their intentional / accidental violations of applicable rules and the consequences of such violations;

-mandatory public access to committed economic crimes.

The key decision to combat economic crime in the Netherlands was the creation of the National Integrity Agency (ANI); its main functions are as follows:

-support and implementation of the policy of professional ethics and integrity through the organization of various conferences and seminars 
and the provision of necessary information to organizations;

-monitoring of national and international experience in the sphere of integrity (collection, dissemination and exchange of information and knowledge among government agencies);

-development of tools for the implementation of integrity in government organizations (that is, improvement of activities towards conducting discussions and assessment of the level of integrity).

In fact, ANI creates an atmosphere of open culture; it develops and implements models of optimal work of management staff in public services through the provision of relevant information and training.

Germany has introduced new methods and measures through experimentation. In Lower Saxony, for instance, a pilot project has been launched to receive anonymous reports from citizens about economic law infringements. 184 reports were received, of which 124 criminal cases were opened over the course of a month. One third of the reports concerned exclusively corruption. This ensured the development and implementation of the federal project "Concept of Economic Crimes and Corruption". Special guidelines for bribery have been developed and issued for auditors and tax inspectors in order to prevent mistakes that could lead to economic violations of the law.

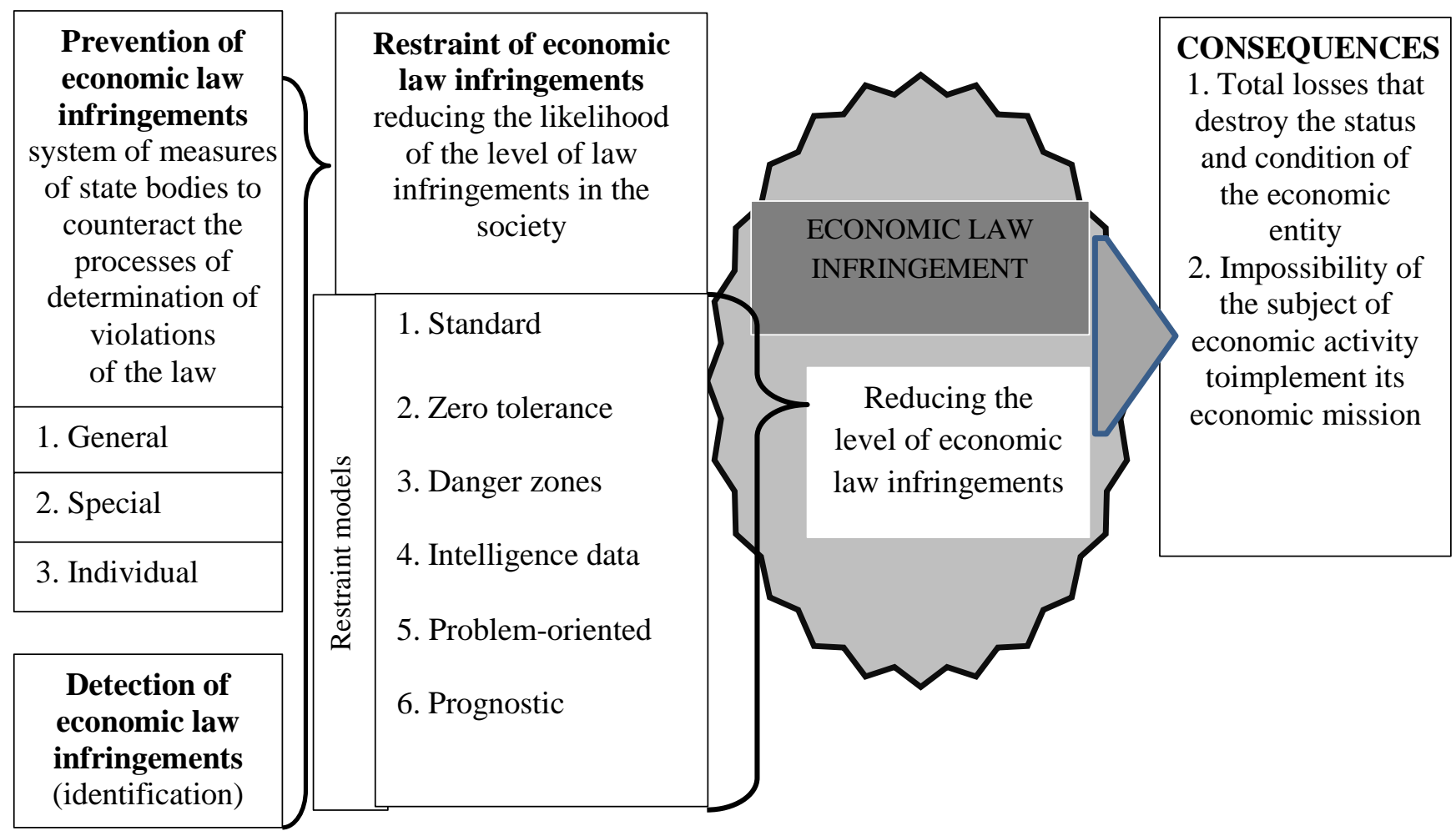

In the UK, the Bribery Act was adopted in 2011, as well as the Criminal Finances Act was adopted in 2017, according to which confiscation of real estate worth more than 50000, 00 GBP is an effective way to combat economic crime, in case the owner does not prove the legality of the source of funds spent on its acquisition.

The law "On transparency of combating corruption and modernization of the economy" was introduced in France in 2016, which provides the following means of counteracting economic law infringements, namely:

- creation of a register of "representatives of interests" (legal entities, associations, nongovernmental organizations that interact with officials and participate in the development of regulations);

-consolidation of the procedure for transparency in obtaining funding by political parties and candidates for elections;

- ensuring adequate protection of whistleblowers concerning combating economic law infringements;

-obligatory informing of the President and the Prime Minister about inaccuracies, discrepancies in the declaration of income, expenses of members of the government.

Generalization of the experience of the world's advanced countries in the prevention and overcoming economic law infringements makes it possible to form the concept of modern means and methods of combating economic crimes (Figure 1). 
Fig.1. The concept of modern tools and methods of combating economic law infringements

Let's consider the current models of deterring economic law infringements.

The standard model is a set of tools of a general nature with clearly defined interconnected regulations providing for the implementation of social diagnostics without the use of automated systems. It is implemented in social work through various regulated surveys and interviews; it helps determine the place and time of the most effective use of force and means to solve crimes.

The model of zero tolerance is aimed at preventing social problems or life crises of certain groups of the society or preventing future crimes through restrictions and sanctions (within the law) even for minor law infringements or misdemeanors in order to eliminate undesirable behavior. Based on the results of the practical application of the zero tolerance model, American scientists, together with the Police Department, developed the CompStat and TrafficStat approaches, which provide for the correction of the organization of police work taking into account weekly statistical reports on the activities of each law enforcement unit.

The model of dangerous zones in deterring economic violations of the law is a well-established technique based on a combination of objective quantitative statistical data on the collection of data by operational and investigative methods (observation, intelligence method) and subjective qualitative expert assessments, analysis of operational and intelligence information of law enforcement agencies (interviews, questionnaires), the results of criminal proceedings, measures taken in the society in order to structure the analysis of available information about threats and possible consequences of the manifestation of risks. This ensures the timely identification, seizure and confiscation of proceeds obtained by crime and effective blocking of sources of financing economic law infringements. As a matter of fact, law enforcement agencies identify the geographical foci of the most frequently registered law infringements, which are ranked by the highest concentration of their species and types; this makes it possible to form the appropriate "thermal maps" with colored selection of zones.

The specificity of the intelligence data model in deterring economic violations of the law is the primary focus on the collection and accumulation of (intelligence) data by operational-search methods (observation, covert intelligence based method). As a result, according to the cyclical algorithm, law enforcement agencies develop effective solutions.
Problem-oriented model of deterring economic violations of the law involves eliminating the causes of offenses through the SARA algorithm (Scanning, Analysis, Response, Assessment). At the first stage (scanning), problems are identified in a separate area that require a priority solution. At the second stage (analysis), their analysis is carried out with software application. At the third stage (response), active measures are taken to solve the problem; at the fourth stage (assessment), their effectiveness is assessed.

A predictive model of deterring economic violations of the law centers around using various quantitative methods, the application of artificial intelligence systems in order to identify in advance the approximate time, place or persons who will be related to the crime. Prognostic analysis is carried out by a complex method. Simultaneously, the histories of the offenders' behavior and their surroundings (predicting offenders) are analyzed and the identification of persons who could potentially become victims of crime is made (predicting victims); predicting criminal collaborations is carried out, potential cooperation between offenders and the type of crime is predicted; ultimately, the place of crime is predicted (predicting crime locations).

Another approach towards reducing economic law infringements is the formation of a specialized law enforcement agency (Bureau of Financial Investigations) in some countries (Austria, Poland, Georgia, the USA, Sweden, Italy and Lithuania). The Bureau of Financial Investigations operates on the basis of the ILP concept ((Intelligence-led policing). The pre-trial investigations carried out by the Bureau allow organizing the activities of law enforcement agencies in order to prevent the manifestation of economic law infringements. That is, the ILP methodology works with databases and information that is not related to a specific economic law infringement. The pre-trial investigation is carried out by forensic analysis tools and by specially trained detective analysts. Based on the processed information, law enforcement agencies determine the object of attention of the future crime. In practice, this model makes it possible to identify and analyze economic law infringements prior their implementation. This highly intelligent automated model with application of forensic analysis software (I2, Maltego, Palantir, Watson, IDAL, SAS, Semantrum) makes it possible to focus on exposing criminal groups, criminal infrastructure, schemes and technologies of economic crimes, implemented through 
methodological assessment of risks and threats (SPSS, SWOT, PEST, SOCTA).

The conducted analysis of counteraction to economic violations of the law determines the use of tools and methods for detecting and preventing economic crime in the direction of modern powerful information and software systems based on artificial intelligence. In other words, the restructuring of the activities of law enforcement agencies from a reactive system of responding to crimes to a proactive system is taking place, focused on their prevention (see Table 1).

Table 1. Elements of a proactive system for combating economic violations of the law

\begin{tabular}{|c|l|}
\hline $\begin{array}{c}\text { The basic elements } \\
\text { The structure of } \\
\text { participants }\end{array}$ & $\begin{array}{l}\text { Combining efforts of various services of law enforcement and other } \\
\text { government agencies }\end{array}$ \\
\hline Business processes & $\begin{array}{l}\text { Adjusted system of rules for using risk profiles in order to prevent violations } \\
\text { of the law }\end{array}$ \\
\hline Analytics & $\begin{array}{l}\text { Automatic software filling and updating of databases (data reconciliation } \\
\text { occurs immediately when making changes to one of the databases, as a result } \\
\text { of the analysis of social networks Big data) }\end{array}$ \\
\hline Dynamic response & $\begin{array}{l}\text { Identification and assignation of potential actors in real time and immediate } \\
\text { response by the patrol police }\end{array}$ \\
\hline Informing the public & Use of media, television, online Internet tools \\
\hline
\end{tabular}

Information and technological innovations in the activities of law enforcement agencies, their use of forensic software and automated methodological assessment of risks and threats made it possible to keep the low level of crime in European countries (see Table 2).

Table 2. Dynamics of economic violations of the law in European countries through the crime index (CI) and GDP per capita

\begin{tabular}{|c|c|c|c|c|c|c|c|c|c|c|}
\hline \multirow{2}{*}{ 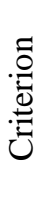 } & \multirow{2}{*}{ Country } & \multirow{2}{*}{$\begin{array}{l}\text { Models of } \\
\text { deterrence of } \\
\text { economic } \\
\text { violations of } \\
\text { the law }\end{array}$} & \multicolumn{2}{|c|}{2015} & \multicolumn{2}{|c|}{2020} & \multicolumn{2}{|c|}{$\begin{array}{r}\text { Change } I_{3} \\
2020 / 2015 \\
\end{array}$} & \multicolumn{2}{|c|}{$\begin{array}{l}\text { Change GDP per } \\
\text { capita 2020/2015 }\end{array}$} \\
\hline & & & $\mathrm{I}_{3}$ & $\begin{array}{l}\text { GDP per } \\
\text { capita }\end{array}$ & $\mathrm{I}_{3}$ & $\begin{array}{l}\text { GDP per } \\
\text { capita }\end{array}$ & Deviation & $\begin{array}{l}\text { Growth } \\
\text { rate, \% }\end{array}$ & Deviation & $\begin{array}{l}\text { Growth } \\
\text { rate, \% }\end{array}$ \\
\hline \multirow{12}{*}{ 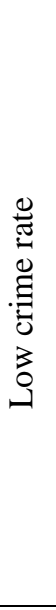 } & Slovenia & \multirow{12}{*}{ 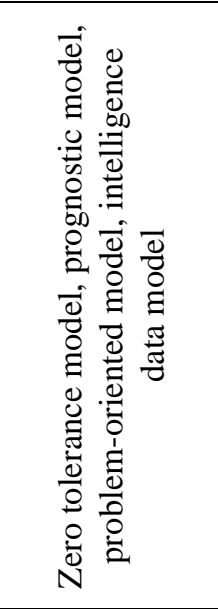 } & 27,01 & 30,918 & 20,95 & 25,039 & 6,06 & 22,44 & $-5,88$ & $-19,01$ \\
\hline & Switzerland & & 26,23 & 58,654 & 21,58 & 81,867 & 4,65 & 17,73 & 23,21 & 39,58 \\
\hline & Estonia & & 26,18 & 28,451 & 23,56 & 22,986 & 2,62 & 10,01 & $-5,47$ & $-19,21$ \\
\hline & Iceland & & 33,87 & 45,74 & 23,7 & 57,189 & 10,17 & 30,03 & 11,45 & 25,03 \\
\hline & Austria & & 26,28 & 47,071 & 24,43 & 48,634 & 1,85 & 7,04 & 1,56 & 3,32 \\
\hline & Croatia & & 29,04 & 21,683 & 24,67 & 14,033 & 4,37 & 15,05 & $-7,65$ & $-35,28$ \\
\hline & Belarus & & 28,24 & 18,347 & 25,02 & 6,134 & 3,22 & 11,40 & $-12,21$ & $-66,57$ \\
\hline & $\begin{array}{l}\text { The Czech } \\
\text { Republic }\end{array}$ & & 32,25 & 32,076 & 25,4 & 22,627 & 6,85 & 21,24 & $-9,45$ & $-29,46$ \\
\hline & Finland & & 26,57 & 41,164 & 25,53 & 48,461 & 1,04 & 3,91 & 7,30 & 17,73 \\
\hline & Denmark & & 25,03 & 47,223 & 26,09 & 58,439 & $-1,06$ & $-4,23$ & 11,22 & 23,75 \\
\hline & $\begin{array}{l}\text { The } \\
\text { Netherlands }\end{array}$ & & 33,34 & 51,29 & 27,15 & 49,623 & 6,19 & 18,57 & $-1,67$ & $-3,25$ \\
\hline & Romania & & 29,99 & 12,813 & 27,82 & 20,933 & 2,17 & 7,24 & 8,12 & 63,37 \\
\hline \multirow{7}{*}{ 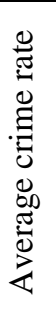 } & Slovakia & \multirow{7}{*}{ 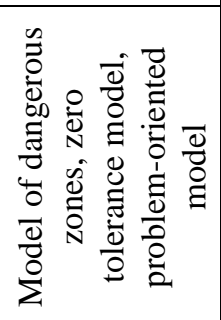 } & 32,77 & 29,975 & 29,81 & 18,669 & 2,96 & 9,03 & $-11,31$ & $-37,72$ \\
\hline & Portugal & & 36,29 & 28,053 & 29,83 & 21,608 & 6,46 & 17,80 & $-6,45$ & $-22,97$ \\
\hline & Spain & & 32,39 & 34,751 & 32,33 & 26,832 & 0,06 & 0,19 & $-7,92$ & $-22,79$ \\
\hline & Lithuania & & 25,55 & 19,883 & 32,75 & 28,587 & $-7,20$ & $-28,18$ & 8,70 & 43,78 \\
\hline & Poland & & 32,31 & 26,622 & 33,13 & 15,304 & $-0,82$ & $-2,54$ & $-11,32$ & $-42,51$ \\
\hline & Luxembourg & & 51,58 & 109,602 & 33,88 & 101,054 & 17,70 & 34,32 & $-8,55$ & $-7,80$ \\
\hline & Norway & & 30,44 & 68,401 & 34,62 & 67,989 & $-4,18$ & $-13,73$ & $-0,41$ & $-0,60$ \\
\hline
\end{tabular}




\begin{tabular}{|c|c|c|c|c|c|c|c|c|c|c|}
\hline & Germany & & 30,64 & 47,254 & 35,14 & 45,466 & $-4,50$ & $-14,69$ & $-1,79$ & $-3,78$ \\
\hline & Hungary & & 43,3 & 15,373 & 35,23 & 26,536 & 8,07 & 18,64 & 11,16 & 72,61 \\
\hline & Latvia & & 36,84 & 24,675 & 37,43 & 17,23 & $-0,59$ & $-1,60$ & $-7,45$ & $-30,17$ \\
\hline & Serbia & & 45,24 & 8,506 & 37,73 & 13,79 & 7,51 & 16,60 & 5,28 & 62,12 \\
\hline & Bulgaria & & 42,03 & 19,286 & 38,55 & 9,826 & 3,48 & 8,28 & $-9,46$ & $-49,05$ \\
\hline & $\begin{array}{l}\text { North } \\
\text { Macedonia }\end{array}$ & & 38,16 & 14,083 & 38,61 & 6,019 & $-0,45$ & $-1,18$ & $-8,06$ & $-57,26$ \\
\hline & Malta & & 25,55 & 37,87 & 39,37 & 28,469 & $-13,82$ & $-54,09$ & $-9,40$ & $-24,82$ \\
\hline & Albania & & 47,27 & 11,284 & 39,86 & 4,898 & 7,41 & 15,68 & $-6,39$ & $-56,59$ \\
\hline \multirow{12}{*}{ 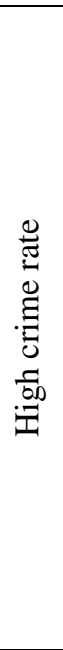 } & Russia & \multirow{12}{*}{ 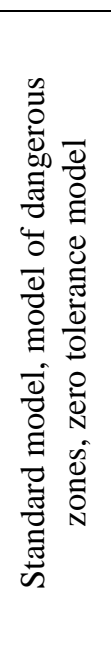 } & 49,34 & 26,207 & 40,6 & 9,972 & 8,74 & 17,71 & $-16,24$ & $-61,95$ \\
\hline & Greece & & 39,44 & 26,303 & 41,3 & 18,168 & $-1,86$ & $-4,72$ & $-8,14$ & $-30,93$ \\
\hline & Montenegro & & 50,58 & 7,933 & 41,56 & 16,057 & 9,02 & 17,83 & 8,12 & 102,41 \\
\hline & $\begin{array}{l}\text { Bosnia And } \\
\text { Herzegovina }\end{array}$ & & 44,11 & 10,526 & 43,57 & 5,762 & 0,54 & 1,22 & $-4,76$ & $-45,26$ \\
\hline & Italy & & 39,23 & 30,657 & 44,24 & 35,96 & $-5,01$ & $-12,77$ & 5,30 & 17,30 \\
\hline & $\begin{array}{l}\text { The United } \\
\text { Kingdom }\end{array}$ & & 42,92 & 41,477 & 44,54 & 39,229 & $-1,62$ & $-3,77$ & $-2,25$ & $-5,42$ \\
\hline & Belgium & & 42,62 & 44,206 & 45,29 & 43,814 & $-2,67$ & $-6,26$ & $-0,39$ & $-0,89$ \\
\hline & Ireland & & 48,64 & 65,481 & 45,68 & 79,669 & 2,96 & 6,09 & 14,19 & 21,67 \\
\hline & Moldova & & 51,58 & 4,268 & 46,03 & 5,054 & 5,55 & 10,76 & 0,79 & 18,42 \\
\hline & France & & 47,6 & 41,431 & 47,37 & 39,257 & 0,23 & 0,48 & $-2,17$ & $-5,25$ \\
\hline & Sweden & & 42,95 & 48,309 & 47,43 & 50,339 & $-4,48$ & $-10,43$ & 2,03 & 4,20 \\
\hline & Ukraine & & 49,6 & 7,995 & 48,84 & 3,425 & 0,76 & 1,53 & $-4,57$ & $-57,16$ \\
\hline
\end{tabular}

Analyzing the data, it should be noted that crime remains a common phenomenon for European countries and its average level is about $35 \%$; there has been a downward trend over the past five years. European countries can be divided into three groups according to the category of crime index (21-28\%; 29-40\%; more than 40\%). This indicator is the lowest in such countries, as: Slovenia, Switzerland, and Estonia. The highest crime rates are observed in Moldova, France, Sweden and Ukraine. It should be noted that the crime rate in the country is not directly related to the economic level of development of the country itself. For instance, economically developed countries (France, Italy, Sweden) have a high crime rate. Consequently, the crime rate is a generalized indicator of the economic condition of the country, its social environment and the action of relevant law enforcement agencies. The largest number of refugees from Africa and the Middle East are observed in Italy, France, Greece; this factor increases the crime rate.

The division of European countries into groups reflects the relationship with the use of models of deterring economic violations of the law. For a group of countries with a low crime rate, the tools and methods of combating economic law infringements are focused on complex systems of forensic analysis and assessment of risks and threats through SPSS, SWOT, PEST, SOCTA software products. For the group of countries with an average crime rate, models prevail, in which information technology innovations are involved to a lesser extent. The exceptions are Germany and Norway, where the system for combating economic violations of the law has a high level of automated software. The third group of European countries in terms of crime is specific, forasmuch as it includes economically developed countries (Italy, Sweden, Belgium, Britain, France, Ireland). Despite the high level of provision of modern automated tools and methods of work of law enforcement agencies in the field of economic law infringements, the crime rate is high in these countries. Economic violations of the law are committed at a high intellectual level and have a highly organized structure. In such countries, as Russia, Moldova, Ukraine, Montenegro, Bosnia and Herzegovina, standard models for deterring economic law infringements are applied.

In 2020, Ukraine has ranked the first place among all European countries in terms of crime. Abuse in the economy measures the index of perception of corruption in points, with 0 points indicating a complete loss of effective governance. In 2019, this figure in Ukraine was 30 points; it was the lowest in 2013 - 25 points. Unfortunately, in 2017, reforms in the anti-corruption system were 
suspended, which negatively affected the level of economic crimes and the Corruption Perceptions
Index in Ukraine (see Fig. 2).

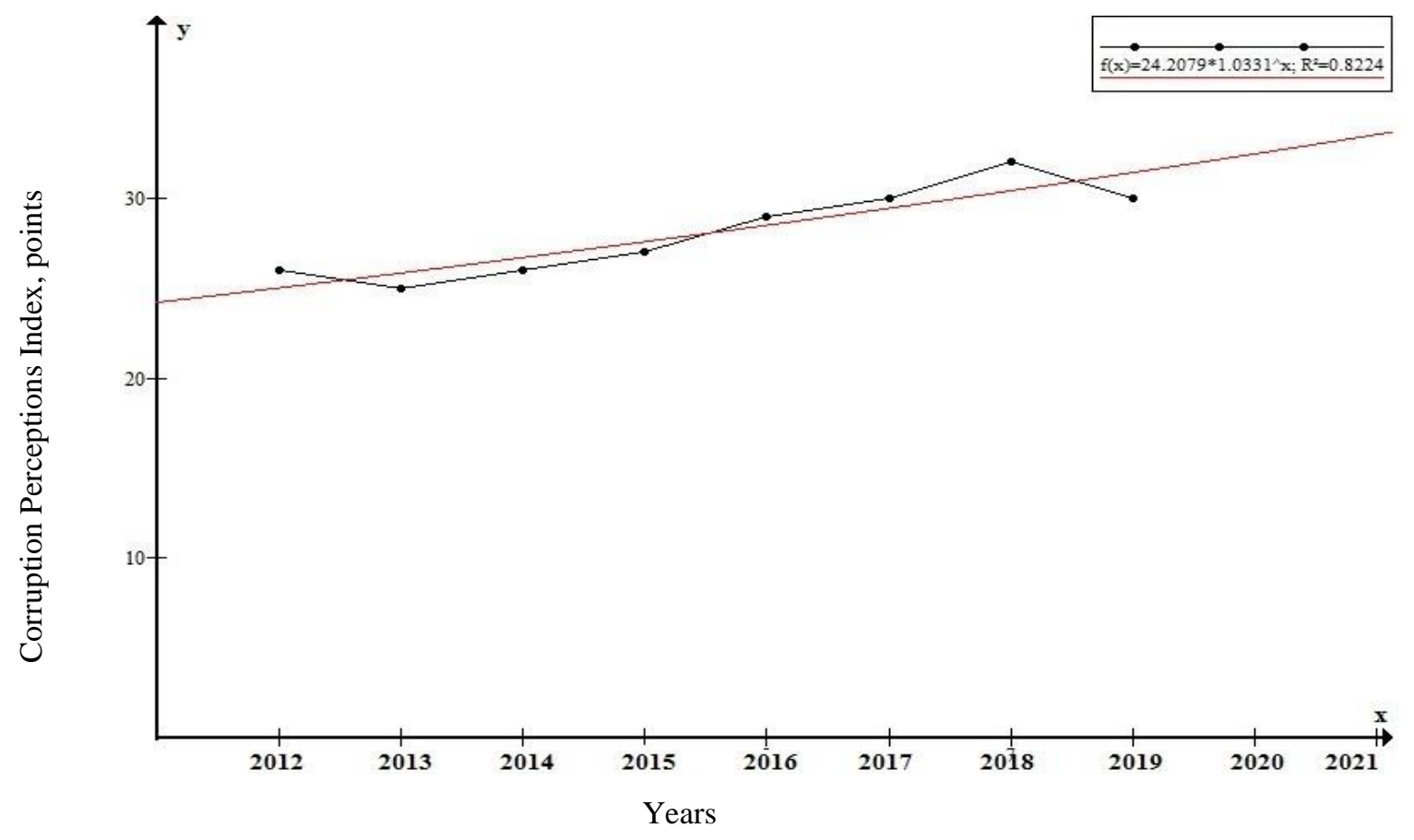

Fig. 2. Dynamics of change in the Corruption Perceptions Index in Ukraine

We use SPSS to determine the level of economic offenses in corruption schemes in Ukraine. The study shows that the most suitable use of the forecast (trend) model, which corresponds to the exponential function in the form of an equation. According to the forecast, the level of economic law infringements in corruption schemes will increase by the calculated exponential function:

$$
(x)=24,2079 \cdot 1,0331^{x}
$$

To assess the accuracy of the model, a coefficient of determination is used, the value of which is $R^{2}=0,8224$.

International experts have provided recommendations on strengthening actions towards combating crime in Ukraine, as follows: 1. Ensuring the effective operation of the register of beneficiaries. 2. Strengthening control over the financing of political parties. 3. Returning trust to the Specialized Anti-Corruption Prosecutor's Office. 4. Deprivation of the SBU and the National Police of powers in the sphere of combating economic law infringements. 5. Punishment of persons, guilty of organizing attacks on anticorruption activists. However, such measures have not been implemented by the Ukrainian authorities yet.
The highest crime rate in Ukraine among other European countries is explained by the decline in business activity, the reorganization of the united territorial communities and the holding of local elections, according to which the entire administrative system of regional government is changing (there was an elimination of inoperable entrepreneurship, and new schemes have not been developed yet). The basic economic factor of economic law infringements is the low level of income and rising unemployment, especially hidden and rising tariffs for housing and communal services. After all, this determines the selfish motivation.

The conducted analysis indicates a steady trend of high levels of economic law infringements in Ukraine. All the outlined makes it possible to conclude, if the government is not interested in real reforms in the coming years, the situation will not improve.

\section{Discussion}

European laws treat economic crimes as encroachments on economic relations or those committed in the economic sphere. Consequently, economic violations of the law are investigated in three areas, namely: property rights violations [9]; violation of the right to economic activity [10]; law infringements in management $[11 ; 12]$. However, 
the study of classification simply and solely does not guarantee a reduction in the level of economic crimes [15].

Despite technologies are changing the way law enforcement agencies work around the world, forasmuch as they affect the analysis of criminal cases and investigations [2], however, not all European countries have developed the appropriate highly intelligent tools and methods to combat economic law infringements, as evidenced by our analysis and selection of a group of countries with a high level of crime index.

The obtained results correlate with the proposals of the Swedish National Council for the Prevention of Crime [22] on the feasibility of implementing measures to combat economic law infringements in the relevant hierarchy. Modern tools and methods of combating economic violations of the law require the transfer to automated digital systems "prevention - detection - deterrence" of law enforcement agencies in the sphere of economic law infringements.

The results of the study note the existence of a pattern between the level of crime and the tools and methods of law enforcement used in the field of economic law infringements in Europe. It has been also noted that Ukraine does not pay attention to the implementation of the outlined tools and methods in the activities of Ukrainian law enforcement agencies, which causes such a high level of economic crime, including corruption.

Some authors conduct their investigations in highly specialized areas of economic law infringements [13] and by regions of the world [9]. There are no comprehensive studies of changes in the methods and means of law enforcement agencies in relation to the general process of development of the world economy and legal law.

The application of new methods and ways of work of law enforcement agencies in the sphere of economic law infringements will reduce the level of economic crimes in groups of countries with a high crime rate. The specified methods and techniques are effectively manifested in combination with the adoption of relevant legislative initiatives (Bureau of Financial Investigations).

\section{Conclusions}

The use of various tools and methods of work by law enforcement agencies in the sphere of economic law infringements ensures the reduction of their number within the country and the prevention of their spread in the international space. While earlier the methods of work of law enforcement agencies were focused only on preventive measures of various levels and directions, then with the development of information technologies and software a radical restructuring of the activities of law enforcement agencies takes place from a reactive system for responding to crimes to a proactive, focused on their prevention. Along with this, each country in the system of combating economic law infringements takes a wide range of measures: from changing the legal framework to improving existing tools and methods of work through the introduction of software products.

In general, it should be noted that changes in the system of law enforcement agencies aimed at overcoming economic law infringements make it possible to outline the concept of combating economic violations of the law, tracing the pattern: prevention - detection - deterrence. The main objective of law enforcement agencies is to prevent economic law infringements on the basis of existing models of their containment. These models assess the probability of implementation of crimes by calculating the level of risks and threats in the software I2, Maltego, Palantir, Watson, IDAL, SAS, Semantrum, SPSS, SWOT, PEST, SOCTA.

Economic law infringements are common in all European countries, however, their level differs significantly, which has made it possible to distinguish three groups of countries by crime rate (21-28\%; 29-40\%; more than 40\%). The lowest crime index is observed in Slovenia, Switzerland, Estonia; the highest crime index is observed in Moldova, France, Sweden and Ukraine. For Ukraine, this situation is a consequence of the manifestation of such economic determinants as a low level of income of the population, an increase in the unemployment rate and an unjustified increase in tariffs for housing and communal services.

The results of the research can be used to determine the level of economic offenses in corruption schemes and trends in the development of tools and methods of law enforcement agencies in the sphere of economic law infringements.

Continuation of research can be a deep analysis of the factors influencing economic violations of the law by selected groups of European countries and evaluation of measures and methods of work of individual law enforcement agencies in the sphere of economic crimes.

\section{References:}

[1] Tayebi M. A. Glässer U. Social Network Analysis in Predictive Policing: Concepts, 
Models and Methods. Springer, 2016, 133 p. https://doi.org/10.1007/978-3-319-41492-8)

[2] Jaitman L. Frontiers in the economics of crime: Lessons for Latin America and the Caribbean. Office of Strategic Planning and Development Effectiveness. 2018. https://publications.iadb.org/publications/engli $\mathrm{sh} /$ document/2018DEC7-Frontiers-in-theeconomics-of-crime.pdf

[3] Möller C. White Collar Crime and Street Crime in Germany. A Comparative Overview. GRIN Publishing; 1. Edition, 2017, 32 pp.

[4] Achim M., Borlea S. Economic and Financial Crime: Theoretical and Methodological Approaches/ Economic and Financial Crime, volume $20,2020, \quad$ pp. 1-71. https://link.springer.com/chapter/10.1007\% $2 \mathrm{~F}$ 978-3-030-51780-9_1

[5] Machin S., Meghir C. Crime and economic incentives. The Institute for Fiscal studies WP, 2017 , $00 / 17$ https://www.ifs.org.uk/wps/wp0017.pdf

[6] Heeks M., Reed S., Tafsiri M., Prince S. The economic and social costs of crime. $2 \mathrm{~d}$ edition. Research Report 99, 2018, https://assets.publishing.service.gov.uk/govern ment/uploads/system/uploads/attachment_data /file/732110/the-economic-and-social-costsof-crime-horr99.pdf

[7] Abubakar Saddiq Sani, Abu Sufian Abu Bakar. Impact of economic and financial crimes on economic growth in emerging and developing countries A systematic review Journal of Financial Crime 26(3), 2020, pp. 910-920 https://doi.org/10.1108/JFC-10-20180112

[8] Souto M. Admission of Guilt in Economic Crimes, Money Laundering, and Criminal Responsibility of Legal Persons. XVII International Research-to-Practice Conference dedicated to the memory of M.I. Kovalyov (ICK 2020) https://doi.org/10.2991/assehr.k.200321.075

[9] Hoctor Sh. Criminalisation of damage to property by South African common-law crimes. Fundamina (Pretoria) vol.25, 2, 2019, http://dx.doi.org/10.17159/24117870/2019/v25n2a3

[10] Draca M., Machin S. Crime and Economic Incentives. Annual Review of Economics, $\mathrm{Vol}$. 7, 2015, pp. 389-408. https://doi.org/10.1146/annurev-economics080614-115808
[11] Marriott L. The Construction of Crime: The Presumption of Blue-Collar Guilt and WhiteCollar Innocence. Social Policy and Society, Volume 16, Issue 2, 2016, pp. 237 - 251. https://doi.org/10.1017/S1474746416000063

[12] Reurink A. Contemporary police strategies of crime control in U.S. and China: a comparative study, Contemporary Crises 66(5), 2016, https://doi.org/10.1007/s10611016-9641-7

[13] Gul Z. Criminals: White-Collar Crimes. In: Shapiro L., Maras MH. (eds) Encyclopedia of Security and Emergency Management. Springer, Cham. 2020, https://doi.org/10.1007/978-3-319-698915_117-1

[14] Recommendation No. R (81) 12 of the Committee of Ministers to Member States on Economic Crime (Adopted by the Committee of Ministers on 25 June 1981 at the 335th meeting of the Ministers' Deputies) https://rm.coe.int/16806cb4f0

[15] Grabosky P. The prevention and control of economic crime in Corruption and Anticorruption, edited by Peter Larmour and Nick Wolanin, 2001, pp. 149-158. 1st ed. Australia, Canberra: Asia Pacific Press. http://pressfiles.anu.edu.au/downloads/press/p228301/pdf /ch091.pdf

[16] Effective and speedy disposal of economic offences cases Lecture delivered Hon'ble Thiru Justice K. N.B ASHA, Judge, High Court Madras at Tamil Nadu State Judicial Academy during the Refresher Course for District Judges on 31.10.2009 http://pressfiles.anu.edu.au/downloads/press/p228301/pdf /ch091.pdf

[17] Berghoff H., Spiekermann U. Shady business: On the history of white-collar crime. Business History, Volume 60, 2018, Issue 3: White Collar Crime. https://doi.org/10.1080/00076791.2018.14147 35

[18] Choi, J., Thum, M. Corruption and the Shadow Economy. International Economic Review, 46 (3), 2005, pp. 817-836.

[19] Borlea, N. S., Achim, M. V., \& Miron, M. G. Corruption, Shadow economy and economic growth: An empirical survey across the European Union countries. Studia Universitatis "VasileGoldis", Arad. Economics Series, 27(2), 2017, pp. 19-32.

[20] ICAEW. Business and Economic Crime in an International Context: a Review of 
International Law and Practice in Relation to Crimes Committed by or on Behalf of Business, 2019, https://www.icaew.com//media/corporate/files/technical/ethics/busines s-and-economic-crime-in-an-internationalcontext.ashx

[21] Ligeti K. and Franssen V. Challenges in the Field of Economic and Financial Crime in Europe and the US. Oxford and Portland, Oregon 2017 https://media.bloomsburyprofessional.com/rep /files/9781509908035sample.pdf

[22] Methods to prevent economic crime. The Swedish National Council for Crime Prevention, Stockholm, Sweden. https://www.bra.se/download/18.cba82f7130f 475a2f1800026145/1371914734482/2005_me thods_to_prevent_economic_crime.pdf

[23] Liang W. \& Zhao Jihong Solomon. Contemporary police strategies of crime control in U.S. and China: a comparative study. Crime, Law and Social Change, № 5(66), 2016, pp. 525-537. https://doi.org/10.1007/s10611-016-9641-7

[24] Tzu-Kuang Hsu, I-Hsun Tsai, The Effect of Tourism Development on Economic Growth in Taiwan: Export Growth as Mediator, International Journal of Circuits, Systems and Signal Processing, Volume 14, 2020, pp. 435439.

[25] Xia Li, Optimization of VRP for Single Distribution Center Based on Improved Saving Method, International Journal of Circuits, Systems and Signal Processing, Volume 13, 2019, pp. 213-221.

[26] Kryvoi Y. Economic crimes in international investment law. International \& Comparative Law Quarterly, Volume 67, Issue 3, 2018 , pp. 577 605 https://doi.org/10.1017/S0020589318000131

[27] Kofanova O., Tereshchenko Y, Kutsyi R., Morhun N., Gushchyn O. Actual situation of computer crime in the credit and financial sphere of Ukraine (modern aspects). Banks and Bank system. Volume 14 2019, Issue \#1, pp.

172-180. http://dx.doi.org/10.21511/bbs.14(1).2019.15
[28] Kvasha O., Zahynei Z., Shapoval M., Kurylo O., Nikitenko V. Corruptive abuses of senior public officials in the banking sphere as a determinant of the Ukrainian economy criminalization. Banks and Bank Systems, 14(2), 2019, pp. 89-105. doi:10.21511/bbs.14(2).2019.08

[29] Yanovska, O., Vilhushynskyi, M., \& Bitsai, A. Protection of property rights: side effects of economic crime investigation. Baltic Journal of Economic Studies, 6(4), 2020, pp. 168-175. https://doi.org/10.30525/2256-0742/2020-6-4168-175

[30] Mozol A. Stanislav, Sukhomlyn V. Yuliia, Khakhutsiak Olha Yu., Bondarenko V. Halyna \& Iryna V. Kalinina. Prevention of Economic Crimes in Ukraine: Problems of Management and Coordination of Law Enforcement Agencies. International Journal of Management, 11 (4), 2020, pp. 585-594. http://www.iaeme.com/IJM/issues.asp?JType $=\mathrm{IJM} \& \mathrm{VType}=11 \& \mathrm{IT}$ ype $=4$

[31] Transparency International, 2019, http://cpi.tiukraine.org/\#/

[32] European Financial and Economic Crime Centre, 2020 , https://www.europol.europa.eu/abouteuropol/european-financial-and-economiccrime-centre-efecc

[33] European Commission. SME Performance Review, 2020, https://ec.europa.eu/growth/smes/smestrategy/performance-review_en

[34] NUMBEO, 2020 , https://www.numbeo.com/crime/rankings_by_ country.jsp

[35] The Law on National Police Ukraine of July 2, 2015 No. 580-VIII, https://cislegislation.com/document.fwx?rgn=78349

\section{Creative Commons Attribution License 4.0 (Attribution 4.0 International, CC BY 4.0)}

This article is published under the terms of the Creative Commons Attribution License 4.0 https://creativecommons.org/licenses/by/4.0/deed.en US 